\title{
Realist Activity Theory for Digital Library Evaluation: Conceptual Framework and Case Study
}

\author{
Mark A. Spasser ${ }^{1}$ \\ Jewish Hospital College of Nursing and Allied Health \\ 306 S. Kingshighway Blvd. \\ St. Louis, MO 63110-1090 \\ mas1200@bjc.org
}

\section{INTRODUCTION}

In this article, I use the term digital library (DL) in a very relaxed and inclusive manner, borrowing Elliott and Kling's (1997) definition of digital libraries as "information systems (IS) and services that provide electronic documents — text files, digital sound, digital video — available in dynamic or archival repositories" (p. 1023). The Flora of North America (FNA) project entails the construction of a digital library, in terms both of this definition and of Sanchez's (1998) definition of a digital library, as “... a virtual space in which scholars conduct research, collaborate and publish their work" (p. 1). Both definitions are consonant with the conception of digital libraries as, in some way, integrating technology, content, and services (Bishop \& Star, 1996), and all three can be underwritten by a realist understanding of complex (i.e., structured and thus irreducible, and relatively enduring) 'things,' as interweaving peoples' situated choices and the collective resources on offer.

Moreover, a critical and heretofore unexamined facet of DL design and use is how library content is assembled and vetted, which in turn has profound implications for subsequent DL usefulness and usability. This article presents a social realist evaluation framework that is then applied to a study and review of the FNA DL and of its context of development and use — specifically, of the organizational issues (or, contradictions) that made its construction and use problematic. Consequently, a significant part of the present analysis focuses on the publication subsystem of the FNA DL - Collaborative Publishing Services - and on how understanding problems related to its design and use facilitates our ability to explain FNA not only as a functioning DL project, but as an organizational form in contradiction-driven expansive development (more will be said both about the role of contradictions and about expansive development later in the article).

THE FLORA OF NORTH AMERICA PROJECT 
Flora of North America (FNA) is a project undertaken by the community of North American botanists to provide a wide range of users — including scientific/academic entities, government agencies, private industry, and amateur enthusiasts - with authoritative information on the names, relationships, characteristics, and distributions of all plants that grow outside of cultivation in North America, north of Mexico. The FNA project is gathering and making accessible, in a variety of media, scientifically authoritative and current information on the names, characteristics, relationships, and distributions of the approximately 20,700 species of vascular plants and bryophytes needed for decision-making, resource management, and innovative research. Thus, FNA is intended to serve as a means of identifying plants of the region, as a means of delineating taxa and geographic areas in need of additional study, and as a systematic conspectus of the North American flora. The Project first received funding in 1987 and is expected to be completed around 2009 (Magill et al., 1999; Morin, Wheatstone, Wilkin, \& Tomlinson, 1989; Morin, 1991).

The major product being produced by the Flora of North America is a comprehensive set of taxonomic treatments for all North American plant species and infraspecific taxa. These treatments are published electronically on the Web and as 30 printed volumes by Oxford University Press. FNA treatments include accepted names, synonyms, bibliographic references, keys for identification, descriptions, economic uses, conservation status, weed status, and distribution data. The nomenclatural and taxonomic data compiled for FNA form the backbone of the Project and constitute a primary information product that will soon be made public. This list of plant names will become an entry point — or portal — into FNA's electronic information and other related botanical information. Despite their synoptic format, many of the treatments present, for the first time, knowledge from a systematist's lifetime of study (Schnase et al., 1997). In Figure 1 are the description and key sections of the treatment for Berberis Linnaeus:

\author{
[DESCRIPTION] \\ Berberis Linnaeus \\ 3. BERBERIS Linnaeus, Sp. Pl. 1: 330. 1753; Gen. Pl. ed. 5, 153. 1754 - Barberry, \\ Oregon-grape, berbéris, algerita [Mediaeval Latin barbaris] \\ Mahonia Nuttall, name conserved; Odostemon Rafinesque \\ Shrubs or subshrubs, evergreen or deciduous, 0.1-4.5(-8) m, glabrous or with tomentose
}


stems. Rhizomes present or absent, short or long, not nodose. Stems branched or unbranched, monomorphic or dimorphic, i.e., all elongate or with elongate primary stems and short axillary spur shoots. Leaves alternate, sometimes leaves of elongate shoots reduced to spines and foliage leaves borne only on short shoots; foliage leaves simple or 1-odd-pinnately compound; petioles usually present. Simple leaves: blade narrowly elliptic, oblanceolate, or obovate, $1.2-7.5 \mathrm{~cm}$. Compound leaves: rachis, when present, with or without swollen articulations; leaflet blades lanceolate to orbiculate, margins entire, toothed, spinose, or spinose-lobed; venation pinnate or leaflets 3-6-veined from base. Inflorescences terminal, usually racemes, rarely umbels or flowers solitary. Flowers 3-merous, 3-8 mm; bracteoles caducous, 3, scalelike; sepals falling immediately after anthesis, 6 , yellow; petals 6 , yellow, nectariferous; stamens 6 ; anthers dehiscing by valves; pollen exine punctate; ovary symmetrically club-shaped; placentation subbasal; style central. Fruits berries, spheric to cylindric-ovoid or ellipsoid, usually juicy, sometimes dry, at maturity. Seeds 1-10, tan to red-brown or black; aril absent. $x=14$.

Species ca. 500 (22 in the flora): almost worldwide.

Many species of Berberis are grown as ornamental shrubs. Some species harbor the black stem-rust of wheat (Puccinia graminis Persoon); the sale or transport of susceptible or untested species is illegal in the United States and Canada. Data on susceptibility of Berberis spp. to infection by Puccinia graminis was supplied by Dr. D. L. Long, U.S. Department of Agriculture (pers. comm.).

The berries of many species are edible and frequently are used for jam and jelly.

The genus Berberis as recognized below is divided into two genera, Berberis and Mahonia, by some authors (e.g., L. Abrams 1934). Species 1-5 below represent Berberis in the narrow sense (characterized by dimorphic stems, with elongate primary stems and short axillary shoots; leaves of primary stems modified as spines; foliage leaves simple; and inflorescences usually rather lax, with acuminate bracteoles and 1-20 flowers; most species susceptible to Puccinia). Species 13-22 represent the segregate genus Mahonia (with stems never regularly dimorphic; stem spines absent; leaves pinnately compound; and inflorescences dense, with rounded or obtuse [rarely acute] bracteoles and 25-70 flowers; never susceptible to Puccinia). Species 6-12, traditionally included in Mahonia when that genus is recognized (L. Abrams 1934), are actually intermediate, resembling Berberis proper in their dimorphic stems, inflorescence structure, and susceptibility to Puccinia, and Mahonia in their spineless stems and compound leaves. Species showing different combinations of the characteristics of the two groups are found in other parts of the world (J. W. McCain and J. F. Hennen 1982; R. V. Moran 1982), so these segregate genera do not seem to be natural. Mahonia is often recognized in horticultural works, but it is seldom recognized by botanists.

\section{SELECTED REFERENCES}

Abrams, L. 1934. The mahonias of the Pacific states. Phytologia 1: 89-94. McCain, J. W. and J. F. Hennen. 1982. Is the taxonomy of Berberis and Mahonia (Berberidaceae) supported by their rust pathogens Cumminsiella santa sp. nov. and other Cumminsiella species (Uredinales)? Syst. Bot. 7: 48-59. Moran, R. V. 1982. Berberis claireae, a new species from Baja California; and why not Mahonia. Phytologia 52: 221-226.

\section{$[\mathrm{KEY}]$}

Berberis Linnaeus

1. Stems spiny; leaves simple; plants deciduous or evergreen.

2. Plants evergreen; leaf blades thick and rigid, each margin with 2-4 teeth or shallow lobes, each tooth or lobe $1-3 \mathrm{~mm}$, tipped with spine $1.2-1.6 \times 0.2-0.3 \mathrm{~mm}$; stems 
tomentose. .... 5. Berberis darwinii

2. Plants deciduous; leaf blades thin and flexible, margins entire or each with 3-30 teeth, each tooth $0-1 \mathrm{~mm}$, tipped with bristle $0.2-1.4 \times 0.1-0.2 \mathrm{~mm}$; stems glabrous.

3. Inflorescences of solitary flowers or umbellate; margins of leaf blade entire. .... 4. Berberis thunbergii

3. Inflorescences racemose; margins of leaf blade entire or toothed.

4. Bark of 2d-year branches gray; each margin of leaf blade with (8-)16-30 teeth; racemes 10-20-flowered. ..... 3. Berberis vulgaris

4. Bark of 2d-year branches brown, purple, or reddish; leaf blade entire or each margin with 3-12 teeth; racemes 3-15-flowered.

5. Leaf blade oblanceolate or sometimes narrowly elliptic, apex rounded or rounded-obtuse; surfaces adaxially \pm glaucous. ..... 1 . Berberis canadensis

5. Leaf blade narrowly elliptic, apex acute to obtuse or rounded; surfaces adaxially not glaucous, often shiny. .... 2. Berberis fendleri

1. Stems not spiny; leaves compound; plants evergreen.

6. Racemes loose (rather dense in B. harrisoniana), 1-11-flowered; bracteoles acuminate.

7. All leaves 3-foliolate; terminal leaflet sessile.

8. Terminal leaflet blade $0.9-2 \mathrm{~cm}$ wide; berries red. .... 6. Berberis trifoliolata

8. Terminal leaflet blade 2.2-3.2 cm wide; berries blue-black. ..... 7. Berberis harrisoniana

7. Leaves 5-11-foliolate (sometimes a minority of leaves 3-foliolate); terminal leaflet stalked on most or all leaves.

9. Marginal spines of leaflet blade 0.4-1.2 $\times 0.1-0.15 \mathrm{~mm}$.

10. Bracteoles (at least proximal ones) leathery, spine-tipped; berries white or red, somewhat glaucous, 9-16 mm, usually hollow; c Texas. .... 11. Berberis swaseyi

10. Bractoles usually membranous, seldom spine-tipped; berries yellowish red to red, not glaucous, 5-6 mm, solid; s California. ..... 12. Berberis nevinii

9. Marginal spines of leaflet blade $0.8-3 \times 0.2-0.3 \mathrm{~mm}$.

11. Berries dry, inflated, 12-18 mm. .... 8. Berberis fremontii

11. Berries juicy, solid, 5-8 mm.

12. Blade of terminal leaflet mostly 2-5 times as long as wide; berries purplish red. .... 9. Berberis haematocarpa 
12. Blade of terminal leaflet mostly 1-2.5 times as long as wide; berries yellowish red. ..... 10. Berberis higginsiae

6. Racemes dense, 25-70-flowered; bracteoles obtuse or acute.

13. Bud scales persistent, 11-44 mm; leaflet blades 4-6-veined from base; anther filaments unappendaged.

14. Shrubs 0.1-0.8(-2) m; teeth 6-13 per blade margin, 1-2(-3) mm, spines 0.1-0.2 mm thick; native, Pacific Coast states, B.C., and Idaho. ..... 21.

Berberis nervosa

14. Shrubs 1-2 m; teeth 2-7 per blade margin, 3-8 mm, spines 0.3-0.6 mm thick; locally naturalized, se United States. ..... 22. Berberis bealei

13. Bud scales 2-8(-14) mm, deciduous; leaflet blades 1-3-veined from base (sometimes 1-5-veined in B. amplectens); distal end of each anther filament with pair of recurved teeth (status of this character in B. amplectens unknown).

15. Leaflet blades abaxially smooth and somewhat shiny (outer surface of cells of abaxial epidermis of leaf plane).

16. Blade of terminal leaflet 1.3-1.9 times as long as wide; lateral leaflet blades elliptic to ovate or broadly lanceolate. ..... 20. Berberis pinnata

16. Blade of terminal leaflet 1.7-2.5 times as long as wide; lateral leaflet blades lance-ovate or lance-elliptic. ..... 19. Berberis aquifolium

15. Leaflet blades abaxially papillose and very dull (outer surface of cells of abaxial epidermis of leaf strongly bulging).

17. Leaflet blades thin and flexible; teeth $6-24$ per blade margin, 0.1-0.25 mm thick; plants 0.02-0.2(-0.6) m. ..... 18. Berberis repens

17. Leaflet blades thick and rigid; teeth 2-15 per blade margin, 0.2-0.6 $\mathrm{mm}$ thick; plants 0.3-2 $\mathrm{m}$ (0.1-0.4 $\mathrm{m}$ in B. pumila).

18. Leaflet blades adaxially glossy.

19. Teeth 6-12 per blade margin; $n$ California and Oregon.

.... 17. Berberis piperiana

19. Teeth 3-5 per blade margin; Arizona and New Mexico.

..... 16. Berberis wilcoxii

18. Leaflet blades adaxially dull, \pm glaucous.

20. Blade margins strongly crispate, each margin with $3-8$ teeth. ..... 13. Berberis dictyota

20. Blade margins plane to undulate or, if crispate, each margin with 9-15 teeth.

21. Plants 0.2-1.2 m; each blade margin with 9-15 
teeth. .... 14. Berberis amplectens

21. Plants 0.1-0.4 m; each blade margin with 2-10

teeth. .... 15. Berberis pumila

Copyright (c) 1996 Flora of North America

Figure 1. The description and key of the FNA treatment Berberis Linnaeus.

While all treatments include geo-referenced distribution maps and many include illustrations, the present study refers only to the textual portions of treatment production to simplify and focus the exposition.

FNA then, is a compilation of the best knowledge available on the patterns of biodiversity among plants in the continental US and Canada. In terms of the number of participants and their geographic distribution, FNA is one of the country's largest scientific collaborations. In sum, FNA provides the only comprehensive, scientifically authoritative treatment of all the plants of North America throughout their range. FNA thus provides a unified conspectus of the flora, is an essential tool for plant identification, and provides systematic discussions of foundational problems and promising new research and exploration.

The FNA Publishing Process: Organization, Medium, and Problems

Authors are invited by the FNA Editorial Committee ${ }^{2}$ to prepare treatments describing various taxa; and collections of taxonomic treatments, including distribution maps and illustrations, are then reviewed, databased, and assembled into published volumes. The FNA Editorial Committee is responsible for identifying experts, soliciting their participation, and managing the various review processes.

The Project's daily activities have been coordinated at the Missouri Botanical Garden in the FNA Organizational Center. A mix of mostly paper and some electronic documents are used throughout. A total of five distinct review processes (taxonomic, regional, nomenclatural, bibliographic, and technical) that range from review of scientific content and style to evaluation of a taxon's conservation status, are performed (sometimes repeatedly) on each treatment once it is submitted. In fact, there are approximately 100 discrete events associated with the publication of a single manuscript, and each event must be tracked and coordinated with other events, occurring serially and concurrently (see Figure 2). 


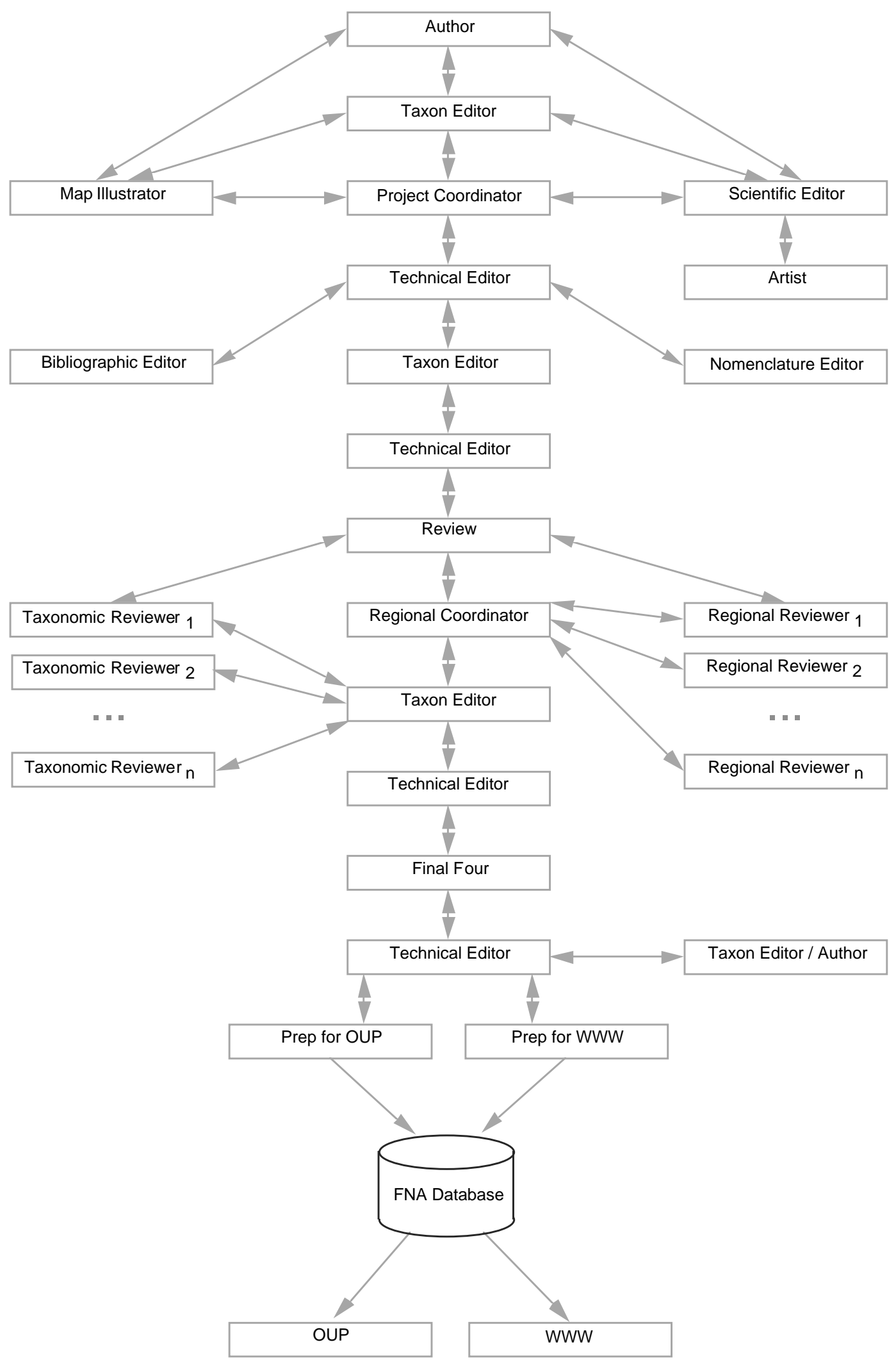

Figure 2. Manuscript flowchart for the FNA project showing steps involved in the edit and review process for each manuscript (adapted from Schnase et al., 1997). 
In Figure 2, boxes labeled technical editor, map illustrator, illustrator, prep for OUP and for WWW, project coordinator, and artist all signal Organizational Center activities. Boxes labeled Taxon Editor and Technical Editor, for example, refer to the same person/role, but at different stages of the manuscript vetting process, demonstrating that the same person, for example the Technical Editor in the Organizational Center, handles the manuscript multiple times. Finally, boxes to each side of the center vertical axis illustrate that steps occur concurrently as well as sequentially. For example, both the Taxon Editor and Technical Editor would see the manuscript at least four different times, while various reviewers would be reviewing the manuscript. Excluded from the figure are some of the author's functions as well as multiple backand-forth exchanges between roles/people.

As many as 300 manuscripts can go into a single volume, and it is necessary to coordinate progress across several volumes simultaneously. This means that participants in the FNA project must effectively articulate a vast number of intra-document, inter-document/intra-volume, and inter-volume interdependent relationships among activities and participants.

Recently, the FNA project has undergone extensive reorganization. A major strategy has evolved to establish semi-autonomous editorial and service centers, the latter providing and coordinating various service activities (bibliographic, nomenclatural, artistic, GIS mapping, and portal), making it possible for editorial teams to work independently and in parallel on major taxonomic groups through the entire publication process, from author solicitation, through edit and review, to electronic and print publication (see Figure 3). 
Treatment Preparation

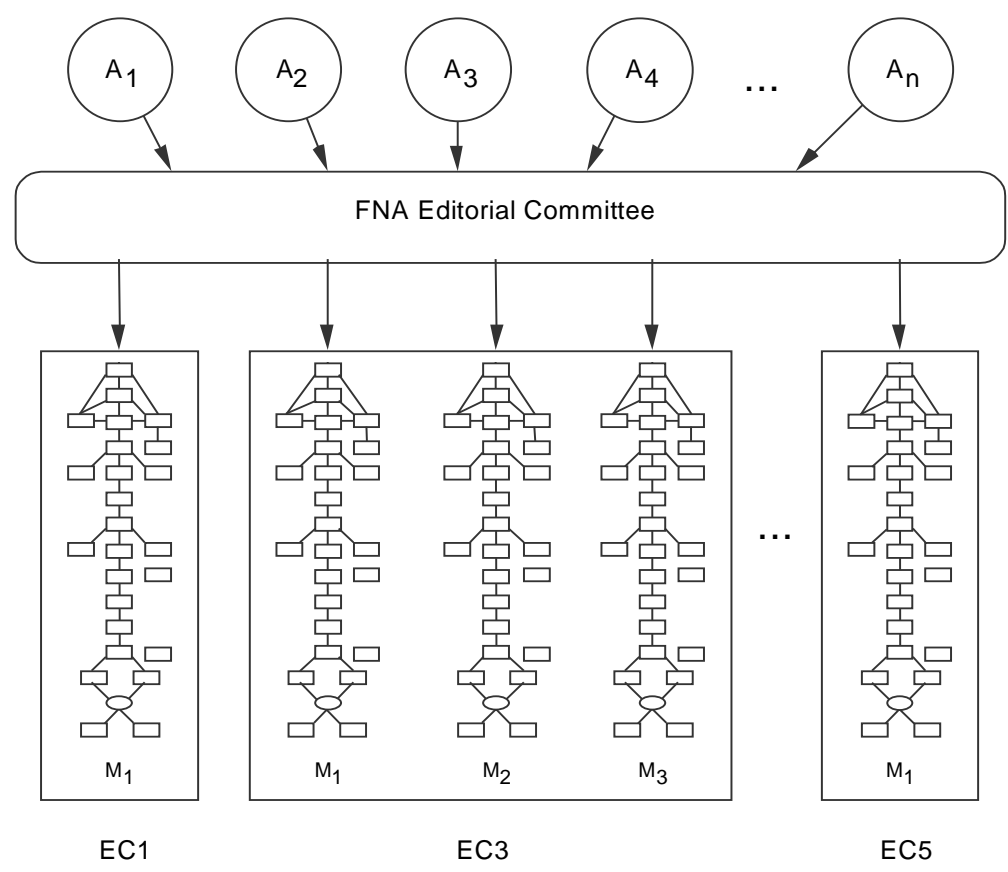

Edit / Review / Database Activities / Publishing

Figure 3. Overview of the major work processes in the newly organized FNA project. Authors $\left(\mathrm{A}_{1}-\mathrm{A}_{\mathrm{n}}\right)$ prepare treatments and submit manuscripts $\left(M_{1}-M_{n}\right)$ that eventually make their way through the appropriate editorial center (each editorial center supervising the publication of multiple, or Mn, manuscripts). Arrows depict major paths of information flow between the treatment preparation and database and publishing components within the Project's editorial centers $\left(\mathrm{EC}_{1-\mathrm{n}}\right)$ (Adapted from Schnase et al., 1997).

The Project's organization can now be depicted as semi-autonomous editorial centers directly communicating and coordinating their work with each other as needed. This distributed work arrangement replaces the centralized arrangement that previously prevailed.

In sum, until recently the FNA project has represented an attempt to adapt traditional methods of small-scale print publishing to a large-scale databasing and electronic publishing effort. While the Project has moved forward (the first three volumes have been published, and intensive work is well under way on volumes 22-24 and volume 4), with its 800+ participants scattered across North America involved in a decades-long effort and with hundreds of manuscripts in various stages of review by different sets of participants at any one time, traditional publishing methods have proved inadequate and inefficient. The 
present research constitutes an initial attempt to explain the expansive reorganization of the FNA project and the role of Collaborative Publishing Services in its collective reconstruction.

\section{Collaborative Publishing Services (CPS)}

In terms of hope and vision, FNA is a big project - a densely stratified work space comprising many collaborators with differing, and sometimes conflicting, agendas distributed across heterogeneous and (semi) autonomous information infrastructures. Because of the huge scope of the Project and the staggering number of inter-task and interpersonal dependencies that must be articulated in publishing thousands of manuscripts contributed by several hundred geographically dispersed scientists, traditional methods of small-scale print publishing have not scaled. Consequently, it was decided that new tools to enable new work processes must be developed if FNA was not to fall even further behind its planned publication schedule (See Spasser, 2000; Tomlinson, Spasser, \& Schnase; and Tomlinson et al., 1998 for research on CPS development- and evaluation-in-use).

CPS is one of a new generation of web-based coordination environments that is being designed both to help reduce the complexity of database publishing in cases, such as FNA, where complexity arises from the inefficiencies in the publishing practices themselves, and to improve the speed and quality of global scientific information gathering and the community construction of large, collaborative scientific databases. It is relatively lightweight, modular, extensible, and scalable. As a web-based environment, it attempts to integrate communication, information sharing (through creation of a common information object repository), and coordination support features and is accessible by unmodified web browsers across heterogeneous, autonomous, and distributed information technology infrastructures. With regard to the last, CPS helps reduce the cognitive load entailed by Project participation (Tomlinson, Spasser, \& Schnase, forthcoming), as well as effectively manage Project-wide collaborative load (Spasser, 1998).

In developing the first version of the web-based project coordination and publishing environment called Collaborative Publishing Services (CPS), FNA management, in consultation with CBI, brought together a multi-institutional team of sociologists and information scientists to help develop a strategy for streamlining — and, in particular, making simultaneous and parallel — the distributed operations of the FNA project. The experience has resulted in a promising new approach to large-scale project coordination. CPS provides a way of managing project information by means of dynamically constructed activity-and- 
information spaces, or role-based views. Role-based views are derived from the socially constructed roles (such as Project Editor, Taxon Editor, Taxonomic Reviewer, Author, etc.) that already exist within the Project. Through these role-based views, Project participants organize information and perform the tasks required in order for the FNA scientific process to work. The various role-based views are delivered through dynamically constructed, personalized web pages.

CPS accomplishes three things that are significant in terms of streamlining the publishing process:

1. CPS lessens individual cognitive load by delegating information and task organizational duties to the interface. CPS does the organization "behind the scenes," and presents to the user information that is in the right place at the right time and in a form that is more explicit and easier to use. CPS transforms the task the scientist confronts by representing it in such a way that the user can readily see exactly how to perform it. This cognitive offloading results in: "What you see is what you need to do."

2. CPS enhances system performance by enabling massively parallel simultaneous use of a large information space via mapping of permissible views plus suites of operations onto individual and group knowledge resources and capabilities. Distributed cognitive systems like the Flora of North America achieve their computational or information-processing power by superimposing several kinds of representations, or representational structures, on a single framework. In our case, the framework is a single, very large information space.

3. CPS structures not just the information but also the tasks. It simultaneously affords and constrains opportunities for the user to interact with the information. Concentrating information organizational complexity in this manner is a particularly efficient way to facilitate simultaneous and tailored access to, and use of, information over a single, large information space.

CPS V1.1 has been fully operational for the bryophyte component of FNA since September 1997. It was extended to the Poaceae group in mid-1998 and to the remaining vascular plant groups in late 1998 on a trial basis. CPS V1.3 became available Project-wide to support FNA's distributed centers in early 1999 (For a detailed history of CPS development and early deployment, see Spasser, 1998).

CPS is the primary document management system for FNA and essentially provides a web-based, platform-independent mechanism for storing, retrieving, and tracking treatments as they make their way through the FNA publishing process. CPS allows editors, authors, and reviewers of individual families or 
groups of families, considered "publishing groups," to carry out their work independently. Within CPS, Project participants can determine the status of a treatment (i.e., where the treatment is in the FNA process, such as "submitted," "out for taxonomic review," or "accepted") and can download copies of all documents pertinent to a treatment, including versions of the manuscript, reviews, email exchanges between authors and editors, electronic copies of maps and illustrations, etc. Access is determined by a person's role. Editors and editorial center staff, for example, can view all documents. Authors can see only their own files, and reviewers can see only designated copies of the manuscript to review.

\section{STUDY APPROACH/METHOD}

\section{The Nature of Social Realist Evaluation}

Realist evaluation is a relatively new evaluation paradigm (Henry, Julnes, \& Mark, 1998; Pawson \& Tilley, 1994, 1995, 1997), positing that outcomes (i.e., outcome patterns or regularities - the things and behaviors that interest us as social scientists) follow from mechanisms (sets of internally-related practices and/or objects) acting in contingently configured contexts. Unpacking the "realist" part of the phrase, we find that realist evaluation is about the real, employs a realist methodology, and has realistic outcomes as its goal. First, evaluation should concern the real, but a reality that is stratified and tensed, involving the interplay between the individual and institution, agency and structure, or the lifeworld and system in contingently configured circumstances over time. Social interaction creates interdependencies (Archer, 1995 refers to these, when reproduced, as situational logics) that develop into real-world customs, rules, and divisions of labor which, in turn, condition — enable and constrain — the interests and opportunities of a given cohort of actors. It is these realities that programs, initiatives, or system implementations seek to change. The key explanatory resource for social realism is not that programs work or that computer-based information systems such as digital libraries are deployed, but that such social forms constitute a spiral of new ideas and transforming social conditions and thus, when successful, introduce the appropriate ideas and opportunities to participants and users in the appropriate cultural and socio-organizational conditions — all else follows from such explanatory propositions.

Second, evaluation should follow a realist methodology, one that is scientific (i.e., systematic and rigorously eclectic) and strives to register the influence of the objective, as well as the situationally emergent. However, scientific evaluation is not method- or measurement-driven, but instead suggests a 
more extensive role for theory in the formulation of evaluation methodology (i.e., realist methodologies are theory-led). Finally, evaluation needs to be realistic, which means both that it is a form of applied research pursued to inform the practice and work of designers, users, managers, etc. and that it modestly attempts to perfect a particular method of evaluation that will work for a specific class of project in well-contextualized circumstances (i.e., the scope of realistic evaluation is middle-range).

Realistic perspectives have been widely adopted in the human sciences, such as accounting (Manicas, 1993), economics (Lawson, 1989, 1994), education (Henry, Julnes, \& Mark, 1998); history (McLennan, 1981), human geography (Sayer, 1985), linguistics (Pateman, 1987), nursing (Ryan \& Porter, 1996; Wainwright, 1997), psychoanalysis (Collier, 1981; Will, 1980), psychology (Manicas \& Secord, 1983), social psychology (Greenwood, 1994; Harré \& Secord, 1972), and sociology (Archer, 1995; Keat \& Urry, 1982; Pawson, 1996; Pawson \& Tilley, 1997; Stones, 1996). Moreover, realism has been employed by several scholars as a comprehensive philosophy of social science (Bhaskar, 1986, 1989; Layder, 1994; Manicas, 1987; Outhwaite, 1987; Pawson, 1989). Finally, the scientific realist perspective is a dominant approach in philosophy of the natural sciences (Aronson, Harré, \& Way, 1995; Bhaskar, 1978; Harré, 1970, $1986)^{3}$. Thus, according to Sayer (1992), “... realism is a philosophy of and for the whole of the natural and social sciences [emphasis in original] (p. xi).

Social Realism in Practice: Methodological Considerations ${ }^{4}$

The strength of evaluation research depends upon the perspicacity of its view of explanation. Because realistic evaluation is at once analytic, stratified, processual, and oriented toward explaining change, it blends into one coherent framework objectivity, intentional agency, and contextual sensitivity. Interventions and systems are always embedded in a range of attitudinal, individual, institutional, and societal processes, and thus observable outcomes are always generated by a range of micro and macro forces that are ineluctably interwoven to produce observed situated activities. Stakeholders' capacity for choice is always conditioned (i.e., constrained and enabled) by the power and resources of their 'stakeholding.' Human activity must be understood in terms of its embeddedness, its location within different (i.e., distinct yet interdependent — non-conflated ${ }^{5}$ ) layers of social reality.

Social realist theory, in general, rests on two commonsensical assumptions: that which we observe in the world is real and it is a product of complex and contingent causal ${ }^{6}$ mechanisms that may not 
be directly accessible to us. In particular, realistic evaluation seeks to understand for whom and in which circumstances a program works through the study of contextual conditioning. ${ }^{7}$ Context is, of course, much more than spatial, geographical, and institutional location; it refers, in addition, to the prior set of social rules, norms, values, roles, etc. and their interrelationships that condition information system usefulness and usability. A key act of design and analysis is thus to identify the people and situations for whom the system is useful/usable by drawing on success and failure rates of different subgroups of subjects within and between implementations.

Realistic evaluation is pragmatic and outcome-oriented. Social realists recognize actors as being active agents, who could always do otherwise (but usually have good reasons not to). Thus, realist evaluation is sensitive to these agents' motives, objectives, and/or goals. Evaluators need to understand what the outcomes of an initiative are and how they are produced. Programs or systems cannot be understood as undifferentiated wholes, or as 'things' because they trigger (or, fire) multiple mechanisms having different effects on different subjects in different situations, and so produce multiple situated outcomes. Outcomes are not inspected simply to verify whether systems are used, but are analyzed to discover if conjectured mechanism/context theories are confirmed and the extent to which they transfactually apply. In effect,

The key is to empty the notions of mechanisms, contexts and outcomes of their architectonic splendour and ... to see them as describing local resources, bounded capacities, specific choices, habitual forms of reasoning, which then act as the routine ingredients for hypothesis-making. ... What is needed is a method which gets closer to the now-you-see-them-now-you-don't patterns of social activities. We need a middleroad strategy for theory-construction so that it becomes neither a jumble of ad hoc stories about why particular events are connected, nor a set of critical claims for the ubiquitous (if metaphorical) presence of master mechanisms (Pawson, undated, pp. 15-16).

Purpose(s) of the Study, or Why study FNA?

The purposes of this research are threefold:

1. To contextualize the use of CPS in terms of the changing organizational form of the FNA Project; 
2. To study the organizational issues that made the adoption of CPS as well as the construction of the FNA DL problematic; and finally

3. To explain, in social realist terms, the re-organizational pressures faced by the FNA Project and the role of CPS in its organizational reconfiguration.

Thus, the overarching focus of this research is to identify the underlying mechanisms generative of the inter-organizational dysfunction that has been observed.

\section{A Minor Digression on Activity Theory}

Being a mechanics of explanation, i.e., supplying only a scaffolding for hypotheses-generation and an ontological chassis for collection of evidence (Pawson, undated), social realism itself makes no assumptions about the content or substance of social reality. Thus, scientific realism is substantively neutral; it ushers in or presumes no specific theory of social life. Accordingly, realism has been conjoined with structuration theory (Pawson, 1996; Pawson \& Tilley, 1997), with Habermasian critical theory (Morrow \& Brown, 1994), and, sketchily but suggestively, with activity theory (Hjørland, 1997). Building upon the latter's work, I propose that realism provides a solid foundation for activity theoretic analyses of social life in general and for work and technology in particular, while activity theory provides a conceptually and substantively rich vocabulary for explanatory reasoning about technologically mediated social praxis.

Activity theory ${ }^{8}$ is a philosophical and cross-disciplinary framework for studying different forms of human practices, and of social life in general, in a multi-level, stratified manner developmentally in time and through space. Activity theorists (see, for example, Engeström, 1987, 1990, 1991) consider the activity (or, activity system) to be the minimally meaningful unit of study. An activity system involves an activity undertaken by a human actor (either individual or collective) motivated towards/by an object (in the sense of an objective), mediated by artifacts/tools, and conditioned by emergent community structural or institutional properties, such as rules, conventions, and roles/divisions of labor.

The basic model of an activity is depicted by Engeström (1987) in Figure 4: 


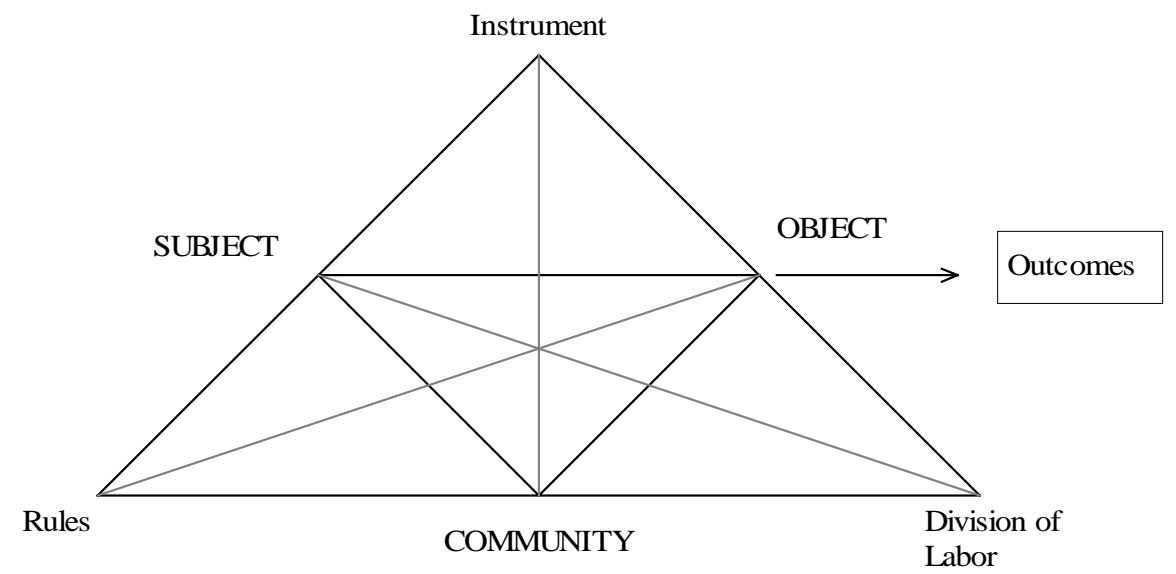

Figure 4. Basic model of human activity system.

An activity system is a triply-mediated, outcome-oriented unit of analysis. Instruments (i.e., resources) mediate the relationship between subject and object; social rules and regulations mediate interpersonal relationships; and roles (i.e., division of labor) condition the relationship between a community of practice ${ }^{9}$ and its negotiated object. This work builds on Engeström's seminal work, and a variant on this basic model of an activity system figures prominently in subsequent analysis. Summarizing the major tenets of activity theory, all human activity is at once artifactually mediated, pragmatic (or, objectively motivated), situated, provisional (historically developing/evolving), and more or less contested (Blackler, 1995).

Data Collection Methods

Activity theory is employed as a middle-range realist theory to initiate, provisionally order, and govern the ongoing conduct of data collection and analysis. Data have been collected from several sources, employing a variety of techniques, such as documentary analysis and extended participant-observation. The idea is to take as many "cuts" at the data from as many angles as is feasible, so as to maximize the strength, density, and validity of theoretical ideas that emerge from data collection and analysis.

Such an approach automatically contributes to multiple triangulations, which strengthens the multiperspectival validity of the conceptual framework developed in, and of the findings of, this work (Yeung, 1997). Specifically, in terms of the present research, triangulation across sources and techniques is especially beneficial to theory generation, as the analytic strategy provides multiple perspectives on an issue, supplies more (and higher quality) information on emerging concepts, allows for cross-checking of assumptions and conjectures, and yields stronger substantiation of constructs (Layder, 1993, 1998;

Orlikowski, 1993; Yeung, 1997; Yin, 1994). 
A source of data especially important to the present research is the intensive participation of the researcher in the ongoing activities of the FNA project. As the Bioinformatics Coordinator and CPS Analyst, I have had access to the inner workings of Project management as well as to the informal and more or less spontaneous activities in the Organizational Center (OC) at the Missouri Botanical Garden, since May 1997. This immersion in the FNA project as both a participant and an observer provides a rich source of data, as well as a deeply grounded context for the analysis of other sources of data. Similar to that described in Näslund (1997), “... my role can be characterized as a participant observer of issues closely related to usability, and as an observer participant regarding other issues in the project" [emphasis in original] (p. 173). Both role variants facilitated the sort of unstructured interactive interviewing that makes possible the study of individual in their contingently configured casual contexts. In this way, data collection for research and for formative system evaluation happily coincided.

Moreover, a large and, more importantly, living corpus of such written materials as organizational documentation and communications (e.g., minutes from committee meetings) about the development and current use of written coordinative mechanisms and the design of CPS were analyzed to help further contextualize and situate the participant-observation. In addition, notes from selected interviews, use sessions, and meetings were content analyzed. Another important source of data was feedback from users as they learned to use CPS over time. Communication with the analyst, the FNA bryological community's primary point of contact with the system development effort, was facilitated by mailto links on each CPS web page. Input from CPS users was important because their questions and comments were used both to contextualize system use and, as a filtering mechanism, to elicit extended feedback from selected users. Feedback from users about their difficulties or problems using CPS provides protocol-analytic data to the extent that users were encouraged to reconstruct what they did and saw and even to anticipate what they planned to do.

Case studies allow researchers to trace phenomena over time, which is essential if the interplay of (inter)action and its causally efficacious conditions are to be effectively separated and analyzed.

The realist case study approach employed in the present research is depicted in Figure 5. 


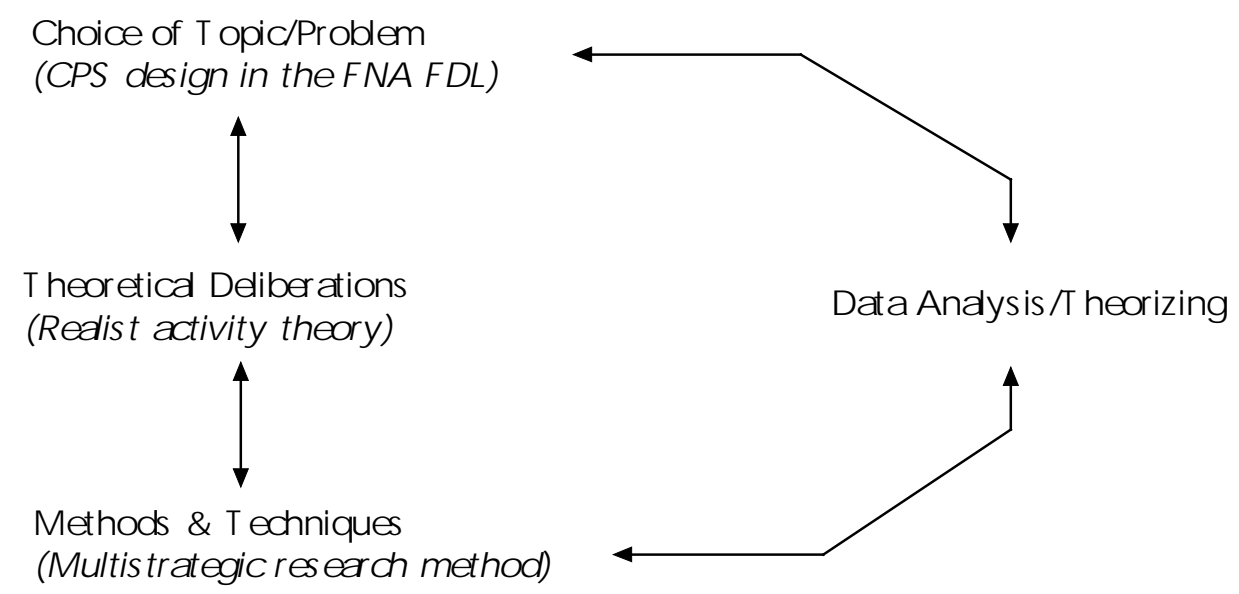

Figure 5. Realist case study research methodology. Italicized elements refer to its application in the present research (adapted from Layder, 1998).

Inspired by key realist and activity theoretic principles, the case study approach employed in this research is deliberately sensitive to, and equally privileges, the contextual conditions of behavior. Moreover, by exhaustively specifying and contextualizing the findings (or, outcomes), previously and/or emergently developed theory can be used as a revisable template with which to constantly compare the results of other social realist case studies. In this way will social science cumulate coherently.

\section{STUDY FINDINGS AND ANALYSIS}

The approach to understanding the evolution of the FNA project that is summarized here is based on realist activity theory (developed earlier in the paper) and has been developed during an eighteen month, ongoing study of the Project. Because detailed presentation of the empirical work is beyond the scope of this paper, aspects of it are drawn upon to illustrate the application and development of the framework used to analyze the FNA project. Thus, while this presentation can only suggest ways in which the theoretical approach developed herein can be used to evaluate trajectories of DL development, in future work this theoretical framework will be explored as a more general conceptual framework for framing DL evaluation.

The present work will focus on describing how attempts to resolve inter-organizational problems (i.e., contradictions ${ }^{10}$ ) among the participants in the FNA project have collectively led to its expansive development (Engeström, 1991) and reconceptualization, which in turn, at least potentially, provides a more hospitable environment for the development and deployment of CPS as a publishing coordination environment and viably sustainable boundary infrastructure (Bowker \& Star, 1999). A couple of the steps that Engeström includes in cycles of expansive development will perforce be the focus of future work. An 
additional way in which this presentation simplifies actual cycles of expansive development is by suggesting that the steps progress in a linear fashion, with no overlap between them. In fact, reality as lived and experienced is never so tidy. ${ }^{11}$ The cycle of expansive development proceeded as described below.

Ethnography of trouble: describing and explaining the initial situation.

In Figure 6, FNA depicts an activity network, whose primary communities of activity are the Center for Botanical Informatics (CBI); Flora of North America Organization (FNA O), which represents those responsible for the execution, planning, and oversight of the entire project; and the Flora of North America Organizational Center (FNA OC), the workaday, administrative center of project coordination physically located at the Missouri Botanical Garden in St. Louis. Importantly, since its initial funding in 1989, FNA OC personnel have been the only full-time paid staff in the FNA project (more about this below).

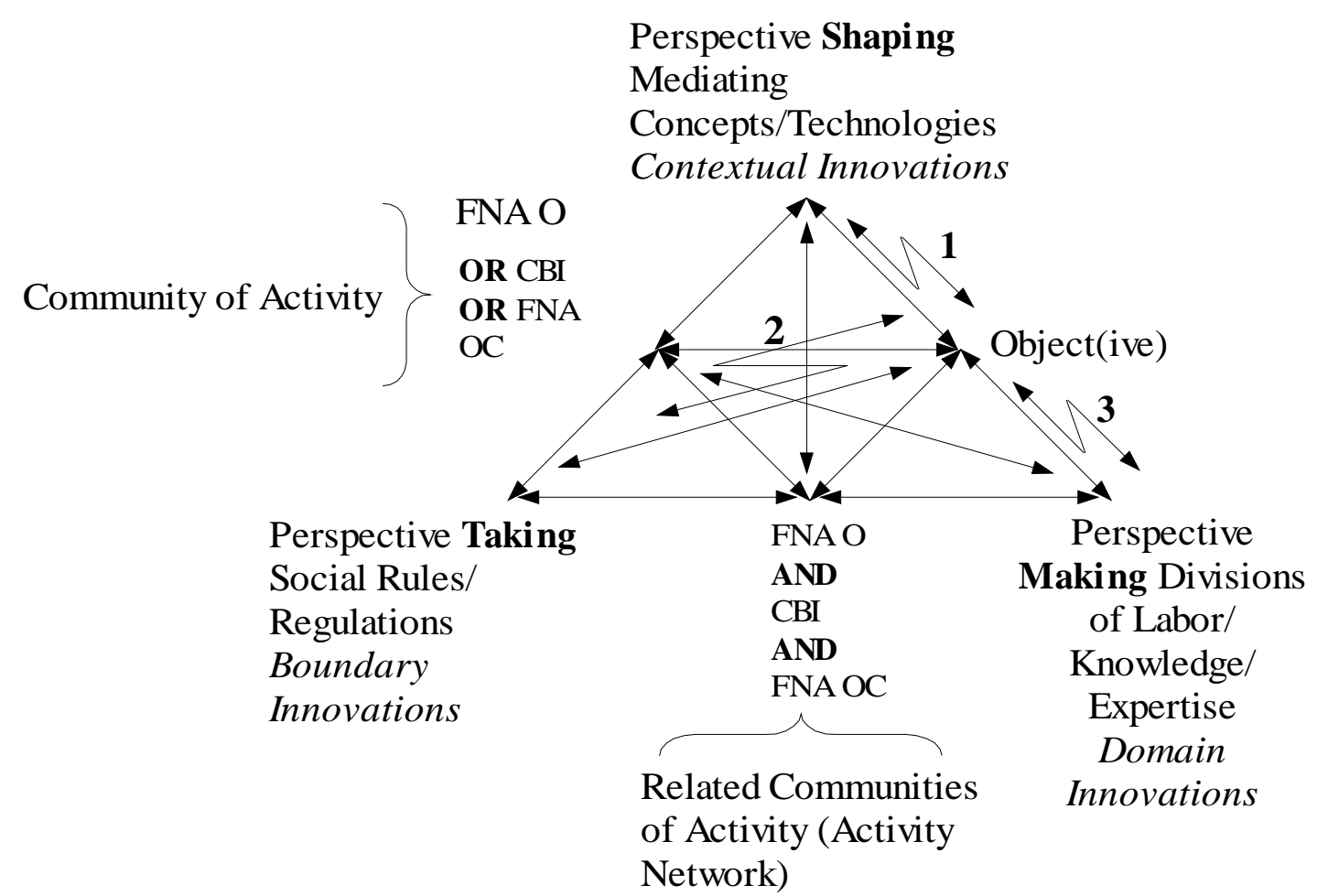

Figure 6. FNA activity network (adapted from Blackler, Crump, \& McDonald, forthcoming). ${ }^{12}$

Figure 6 depicts the FNA activity network as not only multiply mediated, but multiply stratified. Material mediation is embedded in sociocultural mediation. Communities of activity are embedded in activity networks (i.e., networks of related activity systems) And the material, technological, and socioorganizational infrastructures of work-related social interaction (i.e., object-oriented resources, rules, and 
roles derived from the relatively constrained objective(s) of work) generalize to processes of perspective shaping, taking, and making when activity systems are properly located in the networks of related communities of activity in which they customarily operate. The numbered lightning bolts indicate 'contradiction sets' that organize the following discussion.

This approach has been applied to identify and understand key differences between the three communities of activity that are vital to the project's future viability. Factors that help account for differences include: approaches to work adopted by communities of activity, management and leadership styles, and the ways communities of activity define themselves in relation to others in the context of the project as a whole. These factors in turn are of course mediated by conceptual and material artifacts/tools/instruments (contextual resources), formal and informal social rules and regulations (boundary formation and transgression, i.e., innovation), and divisions of labor, expertise, and knowledge/know-how (i.e., domain-specific innovations).

As Blackler, Crump, \& McDonald (forthcoming) explain, with regard to their two-year study of an international supplier of high-tech electro-optical devices to the military:

The infrastructure and priorities that make it possible for particular expert communities to focus on shared goals, to develop an identity, and to act competently can also act as barriers to close collaboration across different communities. Interactions across activity networks are easier to manage in times of relative stability when systems can be developed to minimise conflict or misunderstandings, and more difficult to achieve in times of uncertainty when priorities, methods and group identities may need to be reexamined (p. 18).

For example, both CBI and the FNA OC are physical places with co-located members, and each community of activity has formed a strong sense of shared identity and goals which have interfered with their ability to cooperate to develop an electronic tool to facilitate the work of the project. Moreover, while CBI functions as a source of specialized consultants, charged by the FNA O to help informate (Zuboff, 1989) the project, members of the FNA OC are the only full-time paid staff of the FNA project. In contradistinction to both CBI and FNA OC personnel, members of FNA O are in effect volunteers who are geographically dispersed, and many of whom serve multiple roles for the project. 
Given their differing and inevitably conflicting roles and their equally divergent conception of the objects of their work, the project has been riddled with destabilizing, structurally embedded contradictions from its initial funding. The FNA OC considered their primary objective to be the timely production of the print Flora of North America. CBI was primarily concerned with the design, development, and deployment of CPS as the web-based coordination environment for the construction of the FNA digital library — the electronic Flora of North America. Finally, the FNA O's main concern was the overall identity of the project and its continued funding, which, until very recently, required them to fund FNA OC operations with monies ostensibly earmarked for FNA informatics development.

The FNA OC has never been involved in decisions concerning CBI's role as the Project's informatics consultant; these decisions have been made by those in the FNA $\mathrm{O}$ responsible for managing the project. Accordingly, the FNA OC became extremely competitive with, and suspicious of, CBI's efforts to develop an electronic infrastructure to enable the FNA O to adaptively construct its floristic DL, and again until recently, successfully lobbied for substantial internal funds to enable it to continue its work. Thus, it is easy to see (even in this brief sketch) how the profound differences between the communities of activity constituting the FNA activity network, in terms of both identity and objectives, generate profound difficulties and threaten the viability and continuity of the project in its entirety. In other words, community of activity boundary spanning activities that would lead to project-wide cooperation and overall identity construction and reinforcement have been severely undermined by "pathogens" resident in the very structure or configuration of the FNA network. ${ }^{13}$

Analysis of contradictions: historically and empirically

As can be seen in Figure 6, three sets of contradictions are identified (by numbered two-headed lightning bolts), each focusing on, and emanating from, differing conceptions of the objects of work within and between communities of activity, and which collectively have been fueled by cyclical, yet ongoing, funding pressures. Not only do each of the communities of activity have different conceptions of the same object, but, in some cases, the objects of their work themselves actually differ. For example, for CBI the object of work is CPS; for the FNA OC the print FNA, and for the FNA O a fully and renewably funded project (which, because of funding pressures and conflicting work exigencies, is being transformed from 
the paper-based production of $F N A$ as a traditional multi-volume reference set to the construction of a floristic DL, of which the reference set is one product).

Referring to Figure 6, the focus of contradiction set 1 is on the tension between the object of work and mediating instruments, which jointly shape the context of work. For example, the model of FNA as a floristic DL (a conceptual mediating instrument) used by CBI to guide their work on CPS (its object of activity) is vastly different from, and in conflict with, the model of FNA as a print reference set used by FNA OC to guide their work on the print $F N A$, both of which differ from the management and funding strategies used by FNA O to shape the FNA Project into a fundable entity.

In terms of facilitating project-wide coordination strategies and developing some sense of overall identity, contradictions emanating from differing objectives are profoundly problematic. For example, the contextual resources employed by CBI reinforced its domain-specific (i.e., informatics consulting) orientation and approach -- its sense of technical expertise. However, by restrictively employing the traditional tools of paper-based publishing, based on their conceptual model of small-scale print publishing, the FNA OC developed and reinforced yet another domain-specific orientation and approach. The result of these radically different contexts was to create rather than cross boundaries, rendering the development of either participative (interaction-related) or reificative (artifact-related) connections problematic if not impossible (Wenger, 1998). In terms of the latter, differing investments in domain-specific perspective making activities prevented the development of coordinating boundary objects (Star \& Griesemer, 1989; Star, 1989).

Because each community of activity - CBI, the FNA OC, and the FNA O - construes its purpose and place in the overall Project differently, additional tensions ramify throughout the FNA activity network (see lightning bolts/contradiction sets 2 and 3 in Figure 6). For example, FNA OC construed its object as the publisher-directed publication of the print $F N A$, and thus required all manuscripts to be processed locally and physically (according to a set of elaborate rules and procedures) by its staff to ensure print publication standards were being met. This clearly conflicted with the conception of $F N A$ as first and foremost a digital library, of which one revenue-generating product is the print FNA multi-volume reference set. Moreover, the role of the FNA OC as the centralized, project-wide center of administrative coordination conflicted with the development and especially the implementation of CPS as a means to 
facilitate the fundamentally distributed nature of the Project's work and, even more fundamentally, with the conception of FNA as a digital library and as a fundable testbed for studying and supporting large-scale and highly distributed knowledge work.

Until recently, the FNA activity network could be diagrammatically characterized as follows:

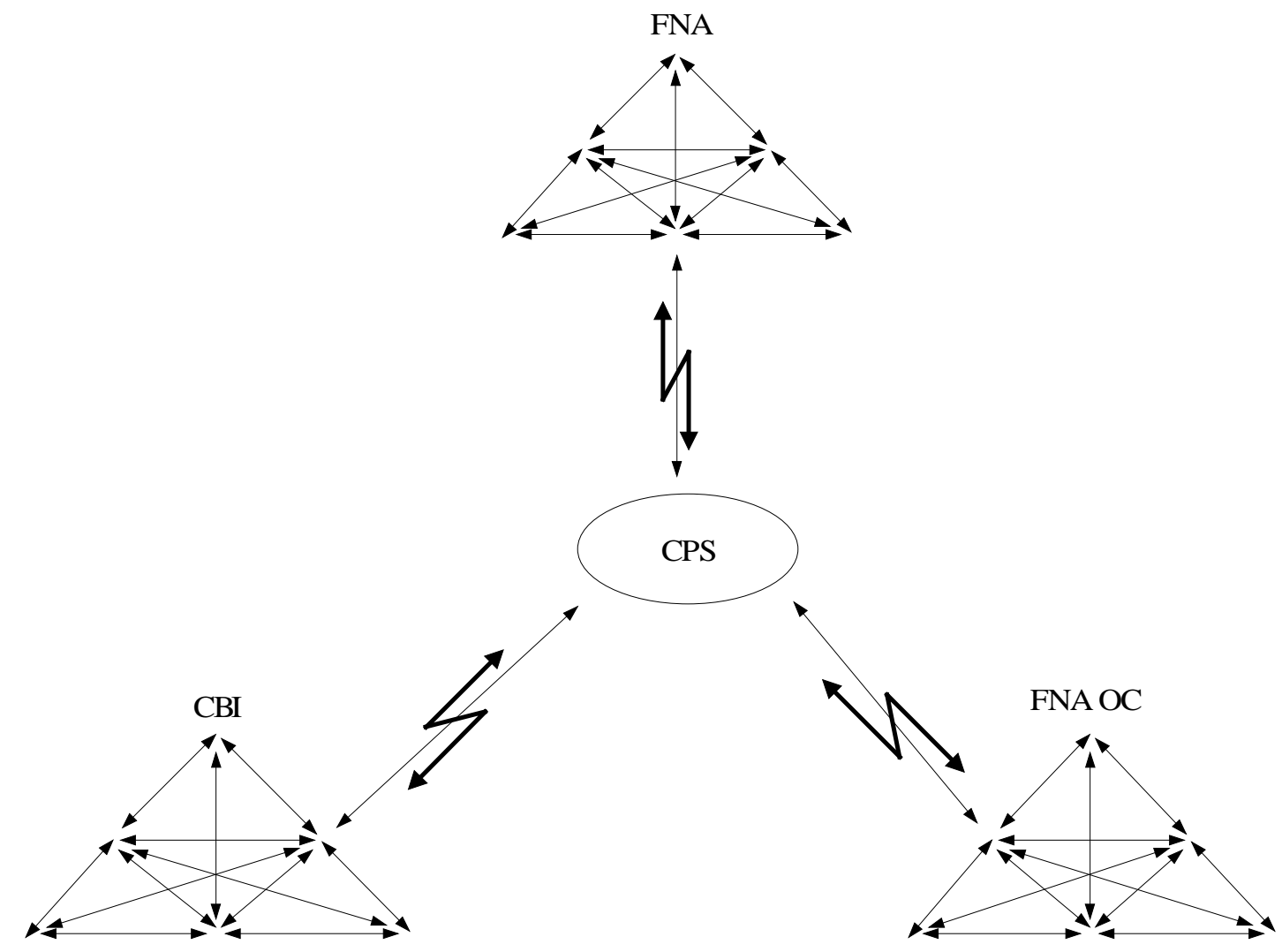

Figure 7. Contradictions in FNA activity network.

The network was deeply fragmented because of differing and incompatible objects, identities, and differing contexts of work. Instead of providing a common or shared object of interest and work, CPS became an arena of conflict. As Boland \& Tenkasi (1995) astutely note, "boundary objects can, of course, be a center of intense conflict as easily as one of cooperative effort. Creating and reshaping boundary objects is an exercise of power that can be collaborative or unilateral" (p. 362). In terms of the analysis above, such a situation is likely to develop in the absence of a collectively held vision of future direction. Not surprisingly, the outcome has been a complex project whose work is behind schedule and whose very existence is threatened by votes of no confidence on the part of benefactors and funding agencies.

Ethnography of transformation: describing and explaining the new situation 
Recently, the FNA project has undergone a dramatic change in its structure, which is largely, if not exclusively, due to the need to resolve the contradictions described above (as well as many others) under renewed and intense funding pressures. The current funding for the project ran out at the end of calendar year 1998, which forced project management to confront several particularly internecine contradictions: FNA as primarily a print reference set or a digital library; adequacy of small-scale print publication practices or the necessity for implementing web-based database publishing and DL construction techniques; and the FNA project as a centrally administered activity system or fundamentally distributed activity network (in the parlance of realist activity theory). The way to resolve these contradictions has come in the form of a newly co-constructed organizational form and context:
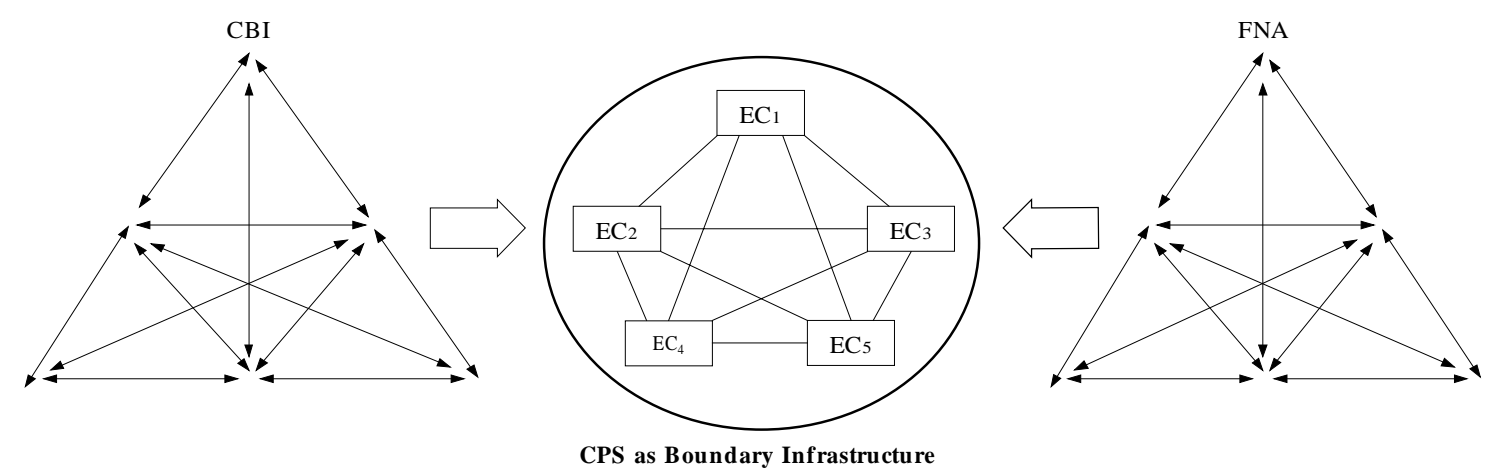

Figure 8. The emergence of the new enabling organizational form: FNA as distributed network of semiautonomous publishing centers.

As can be seen in Figure 8, the FNA Project has been radically re-construed as a decentralized network of semi-autonomous editorial centers (EC) whose work will be at least partially coordinated by a newly designed CPS. The FNA OC has been reconfigured as one of five editorial centers (it will however be the site for a couple service centers as well). In effect, CPS has been upwardly (or forwardly) contextualized, by creating a new, more inclusive perspective for the future of the entire FNA activity network: from the FNA project as centralized structure centered in the FNA OC to FNA as network of semi-autonomous editorial centers; from print $F N A$ multi-volume reference set to $F N A$ as a floristic digital library; and from CPS as optional tool/application to CPS as an integral working coordinative boundary infrastructure serving multiple communities of activity, including the newly reconstituted FNA OC, simultaneously. 
However, apparent success may be short-lived. As Engeström (1990) reminds us, a “... new descriptive 'what' artifact [e.g., FNA as a floristic digital library] may provide for temporary involvement and discussion - but it alone is not likely to achieve much change in the practical actions of the community members. Correspondingly, a new algorithm or a new explanatory model [e.g., CPS] alone will probably remain a curiosity, no matter how obvious its need may be to the researcher [e.g., CBI]" [emphasis in original] (p. 193). Neither involves a needed change in perspective and thus both only downwardly contextualize. Then again, when the FNA project was explicitly re-conceptualized as the highly distributed project it always had been (i.e. acknowledging its true nature, what it is about the project that makes it what it is), together with FNA being formally recognized as a floristic DL, a prospective, perspective-changing, upwardly contextualizing artifact was co-constructed. It was only then that project participants could finally agree that CPS will function as the accepted environment for FNA DL construction.

Finally, however, for the social realist such transformative activity always occurs in some extant context and thus begins from some definite (if unspecified) somewhere. In the case of the FNA project, the new vision of it as a distributed network of semi-autonomous centers was enacted on a small scale from the beginning of this research by bryologists whose lead editor is based at the New York Botanical Garden (NYBG). Given that they study lower, non-vascular plants (as opposed to the rest of the FNA project which covers the vascular flora, the higher plants, of North America), the bryology community of activity was structured differently from the start. They were included in the FNA Project several years after the project was initially funded, only after strenuous lobbying that a flora of North America could not be considered complete if the bryoflora were omitted.

While they were begrudgingly admitted to the project and are represented on project-wide committees, the bryologists have formed an especially tightly integrated community of activity, often holding their own editorial meetings and communicating intensively among themselves. And crucially for the present work, they have, for the most part, chosen not to work with the FNA OC and instead to use earlier versions of CPS to coordinate the publication of their FNA contributions. While there have been problems with these earlier versions of CPS, the bryology community of activity has worked (not always harmoniously) with the CBI informatics team to iteratively develop CPS and, in the process, have modeled not only the new perspective of the FNA project as a truly distributed network, but also a more adaptive 
and constructive approach to information infrastructure design, development, and possible deployment. In fact, the transformative potential for the project as a whole was prefigured and at least partially modeled by the autonomous emergence shortly after this research began of the bryoflora center at the New York Botanical Garden.

As the example of the bryology community of activity illustrates, the FNA Project is both highly stratified and relationally differentiated (Stones, 1996). Social systems (i.e., activity systems or communities of activity) do not exist in a vacuum, but are always in contact with the differentiated powers and liabilities of the objects, processes, people, and practices in other systems. Indeed,

for the standard view of science, the world is a determined concatenation of contingent events; for the realist it is a contingent concatenation of real structures. And this difference is monumental. [emphasis added] (Layder, 1990, p. 14).

The difference was certainly monumental for the bryology group at NYBG, which in turn made a monumental difference to the development of the FNA Project as a whole. In the open, stratified, and differentiated world that is the FNA Project, its development could never have been predicted because the consequences of the interaction between the unique configuration of structural processes (e.g., the necessary independence of the bryology community of activity) and such contingently intervening factors as funding deadlines and national research priorities can never be captured by simple empiricist logic (for the realist, human beings are spontaneous loci of causality - generators of social behavior rather than simple transmitters of external constraints). The ontology of any non-trivially complex activity network is simply too richly variegated. However, what has happened can be causally explained (or evaluated), which is the vital and generative province of realist social science.

\section{CONCLUSIONS}

The FNA Project, along with CPS, is emerging and evolving as this is being written. Drawing conclusions about the ultimate form of the former or the usefulness and productive integration of the latter are thus impossible. However, while the new funding cycle that triggered the crystallization of the FNA project as a network of semi-autonomous centers has not yet begun, the vision described in the ethnography of transformation above is guiding all current project developments, and it is highly likely that the trajectories outlined above are at minimum directionally accurate. 
However, while conclusions are hard to come by, the analysis in the present work has demonstrated the utility of a realist activity theory conceptual framework for ecologically evaluating the socio-organizational and institutional embeddedness of computer-based information systems, such as digital libraries, and explaining the contextual conditioning of our experience of them. Such a framework includes a concern with intrinsic (or generative) causation (e.g., latent systemic contradictions); a stratified and relationally differentiated view of social life (e.g., material and socio-organizational mediation, activity systems related by shared objects and identities into activity networks); and cycles of expansive development/learning/object co-construction in terms of the temporal patterning and interplay among structural conditioning, social interaction, and structural reproduction, elaboration, or transformation.

For the social realist, all valid social scientific research, and even more so for the evaluation of social systems (of which DLs are paradigms), must inhabit the middle-range somewhere between the Scylla of fables of continuous, unconditioned, and unfettered local construction and the Charybdis of grand narratives of the inexorable, de-peopled, and totalizing march of master mechanisms. To paraphrase Marx's celebrated dictum, people make history, but not in circumstances of their choosing. Instead, the social realist adopts a research strategy of appropriate form and scope for leading and, perhaps even more importantly, federating (i.e., cumulating) empirical inquiry. This type of empirical inquiry leads to the development of a generic fuselage of concepts, which in turn provides a scaffolding for middle-range hypothesis generation and an ontological chassis for evidence collection (Pawson, undated). The social realist "... moves from one case to another, not because they are descriptively similar, but because [she has] ideas that can encompass them both [emphasis in original] (Pawson \& Tilley, 1997, p. 119). It is axiomatic for the social realist evaluating social systems, such as DLs, that the insightfulness and subsequent utility of the evaluation will necessarily and massively depend on the perspicacity of its explanatory vision and means.

So, let us end where we began, with the assertion that this research would be real, realist, and realistic. How so? First, and obviously, this research deals with the real activity network that is the FNA Project. Additionally, the organizational incoherencies and the inter-organizational conflicts and contradictions have been all too real. Second, its methodology is realist in that thoroughly contextualized generative mechanisms have been identified. Lastly, this research has been realistic; its applied focus is on 
better understanding those contradictions so as to improve the fit between CPS, the web-based coordination environment, and the organizational form of the FNA Project, as a truly distributed web-enabled activity network.

Finally, while the conceptual foundations of the framework outlined in this work have been widely accepted throughout the natural and social sciences, social realism has yet to find acceptance in the social informatics, computer-supported cooperative work, and human-computer/computer-human interaction communities (all of which include at least aspects of research on DLs). Thus, to the extent that the analysis is valid and compelling, it is hoped that the ideas contained herein may find greater acceptance in better understanding DL evaluation in its tensed, dialectical interplay with design, development, deployment, and use.

\section{POSTSCRIPT}

As of this writing, the fate of the FNA Project has taken yet another unanticipated turn. The NSF grant that outlines the new organizational form of the Project has been rejected. It was decided that too much of the project is incomplete and that not enough was done for the previous grant. FNA leaders were told not to apply for funding until at least $60 \%$ of the project was complete (estimates are that about a quarter of the project is now finished). The FNA OC is being subsidized by the Missouri Botanical Garden, CBI has been eliminated, and CPS continues to be used by the bryology group. Thus, whether FNA truly becomes the distributed network of editorial and service centers outlined in the grant application, whether CPS can be successfully adopted now that CBI is out of the picture, and whether the fit between FNA's organizational structure and state-of-the-art information technologies can be improved so that the former can effectively capitalized on the availability of the latter, are all unclear and to be determined.. Stay tuned! 


\section{ENDNOTES}

${ }^{1}$ This research was conducted while the author was at the Center for Botanical Informatics, LLC, Missouri Botanical Garden, St. Louis, Missouri.

${ }^{2}$ The FNA Editorial Committee is one of three committees that basically govern the FNA Project, the other two being the Management and Informatics Committees. In the remainder of the article, the governing function of the FNA Project is referred to as FNA Organization (FNA O). Moreover, as pointed out later, FNA $O$ also includes the geographically distributed authors, editors, and reviewers, who collectively provide the content of the FNA DL.

${ }^{3}$ Due to space limitations, this list is far from comprehensive, but it is representatively suggestive of the breadth of contemporary social realist scholarship and concerns. In addition, see, for example, Archer et al. (1998) and Fleetwood (1999) for edited volumes of currently influential critical realists and the websites for the Centre for Critical Realism's annual conferences (the site for the 1998 conference is at www.essex.ac.uk/sociology/ccrcon.html and the site for the 1999 conference is at www.oru.se/org/inst/sam/sociolog/ccr/ccr.html).

${ }^{4}$ While beyond the scope of the present work, some basic distinctions must be at least adumbrated to avoid possible confusion. As developed here, realism must be distinguished from other views or philosophies of science also sometimes labeled 'realist.' The first is empiricism (or empirical realism) in either its naïve that there are some absolutely pre-theoretical observations and sense-experiences that form the basis of human knowledge - or its sophisticated form — that while recognizing the theory-laden basis of observations, the validity of 'scientific' knowledge must nonetheless be judged exclusively in terms of falsifying observational evidence (Layder, 1985). The other position to be contradistinguished is positivism (or logical empiricism) in that realism, as used here, neither scientistically privileges a certain outmoded kind of science (elements of which include: nomothetic covering laws, “... a mechanistic paradigm, a 'designate account' of meaning which implies an unmediated relationship between language and the world, and a 'disengaged entity,' a conception of the person that is disembodied and atomistic, divorced from the social context" (Morris, 1997, p. 331)), nor promulgates the possibility of ever discovering a 'single, true' (i.e., correct, veridical, and unmediated) reality. Either of those two positions has the (unintentionally) debilitating effects of de-realizing reality (the epistemic fallacy of reducing reality/being to our sense impressions, or perceptions, of it) or de-socializing science (the ontic fallacy of reifying facts and reducing knowledge to its object, of analyzing knowledge as a direct, unmediated relation between subject and object, thereby “... effacing its process of production" (Collier, 1994, p. 104)). The realism advocated here is hermeneutically premised and causal/explanatory: human life is inherently social and meaningful, as well as being (and partly because it is) firmly located in the context and history of the natural world. As Morris (1997) correctly observes, “... both interpretation and explanatory accounts (science) draw on the capacity to understand" and "... social phenomena can therefore be understood through interpretive understanding, causal analysis and historical reason (pp. 335, 336). The view I put forward however also recognizes ".. a necessary tension between the real objects of scientific explanation and theoretical explanation itself, and posits no necessary correspondence between our understanding of the world and the way the world really works" [emphasis added] (Isaac, 1987, p. 188). Finally, and consequent(ial)ly, realist social science involves “... a combined 'hermeneutical-dialectical' analysis, one that is critical, hermeneutically informed, as well as cognizant of the object contexts in which communicative processes occur (Morris, 1997, p. 333), and thus “... attempts the interpretive understanding of social action in order to arrive at a causal explanation of its [necessary] causes and [contingent and empirically determinable] effects" (Weber, 1947, p. 88).

${ }^{5}$ Archer $(1995,1996,1998)$ distinguishes three fallacies of conflation. In downwards conflation, structural properties engulf agency via totalizing regulation and socialization processes (holism), whereas in upwards conflation, social interaction produces and reproduces/transforms social structures whose seemingly independent properties result from objectification or domination (individualism). Finally, in central conflation, both structure and agency are indissolubly compressed into an ontology of social praxis because 
they are held to be inseparable and continually mutually constitutive (elisionism, e.g., structuration). In other words, conflation is the more basic conceptual error and epiphenomenalism, in either its upwards or downwards variants, merely a form it can take. For example, central conflation construes neither structure nor agency to be epiphenomenal to the other; instead, they are redefined as mutually constituting and inseparable and, as a result, autonomy is withheld from both (Archer, 1996). Moreover, elisionary analogs of social praxes exist. Layer (1997, p. 7) identifies the following: local practices (Hilbert), discursive practices (Foucault), duality of structure (Giddens), habitus (Bourdieu), figuration (Elias), and joint activity (Blumer).

${ }^{6}$ According to Layder (1985), "realists regard the Humean notion of causality as expressed in the idea of observable, regular conjunction of events, as not being an adequate conception of causality, since in essence it reduces to what amounts to a description and/or prediction of observed and observable phenomena rather that a true explanation of them. For the realist a true explanation must go beyond the establishment of observed empirical regularities and posit causal or generative mechanisms [inherent waysof-acting] which underlie these regularities (conjunctions or events), and actually produce them. A real causal explanation must answer the question of why these regularities exist in terms of the underlying mechanisms which generate them" [emphasis in original] (p. 257).

${ }^{7}$ As Sayer (1992) notes, “... the juxtaposition of necessity and contingency is complex ... the relationship between objects and causal powers is necessary; the relationship between these and their conditions is contingent .... For any particular set of conditions, the results occur necessarily by virtue of the nature of the objects involved, but it is contingent which conditions are actually present" (p. 108). See figure 9 below.
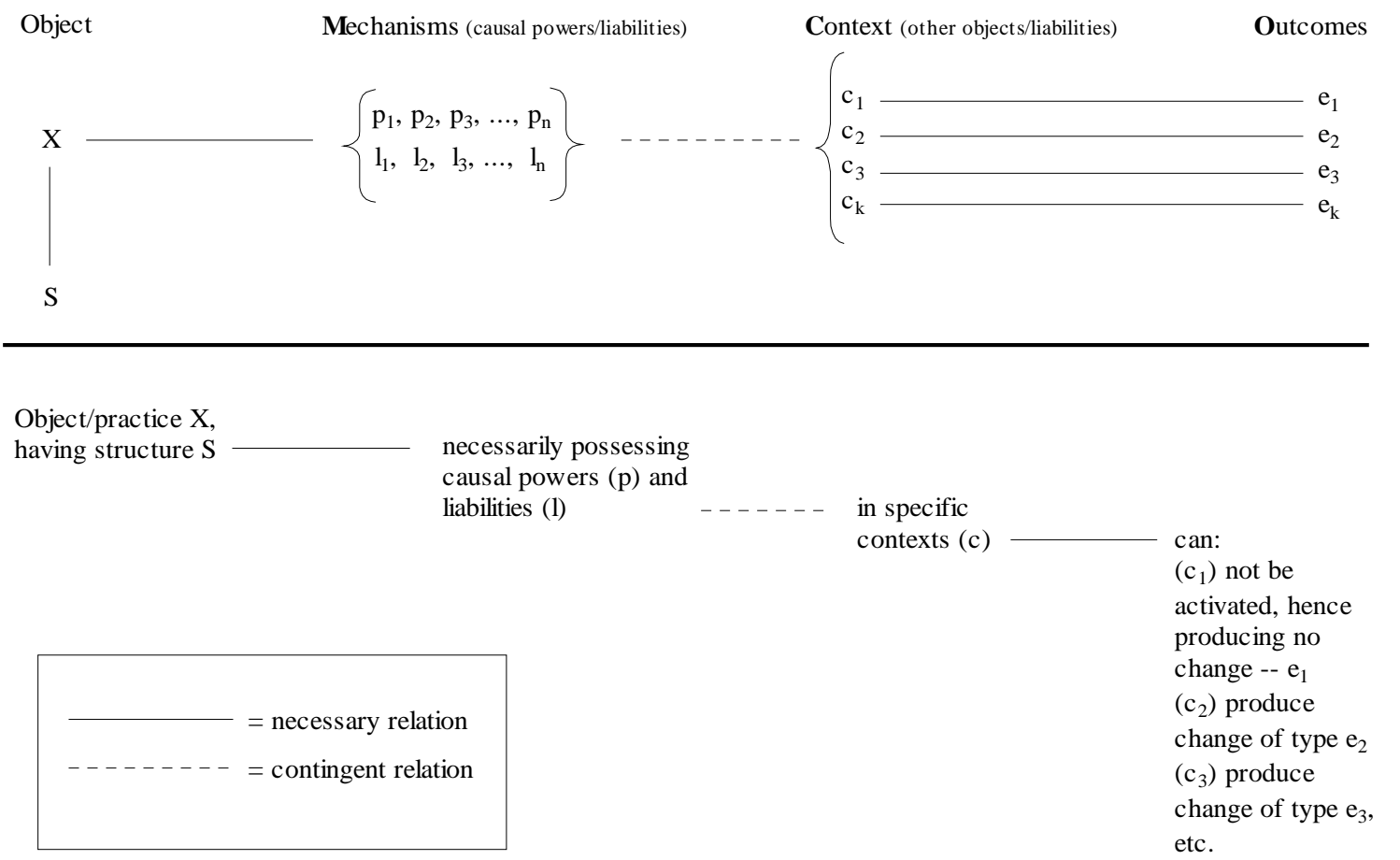

Figure 9. Necessity and contingency in realist explanation (adapted from Sayer, 1992, p. 109).

${ }^{8}$ Nardi (1996), Hasan et al. (1998), and particularly the chapters by Tikhomirov and Kuutti in Engeström et al.(1999) contain useful collections of writings on the application of activity theory to better understand and improve information technology design and evaluation.

${ }^{9}$ The terms activity system and community of activity are used interchangeably. They are middle-range concepts, denoting units of analysis that are both larger and more encompassing (of context) than the actions of isolated individuals and smaller than such amorphously encompassing (and obscuring) analytic units as culture or social system (Blackler, Crump, \& McDonald, 1999, forthcoming; see also Kuutti, 1991; 
Layder, 1993, 1998; and Pawson, undated, for in-depth discussions of the utility of such mid-level conceptual tools).

${ }^{10}$ Engeström $(1987,1995)$ depicts the inner contradictions of an activity system collectively as the generative principle of systemic elaboration or transformation, i.e., development. Contradictions are generative mechanisms (i.e., emergent, internally-related properties of activity systems qua systems) in that “... new qualitative forms of activity emerge as solutions to the contradictions of the preceding stage or form (Engeström, 1987, p. 91). In sum, for activity theory, “... the objective reality is a living system unfolding through emergence and resolutions of its inner contradictions" [emphasis added] (quoted in Engeström, 1995, p. 404).

${ }^{11}$ As Engeström (1991) notes about the cycle of expansive development, “... the research steps ... are an ideal-typical sequence, not necessarily something done in every concrete project of Developmental Work Research" [emphasis added] (pp. 271-272). The present work will focus on describing how attempts to resolve inter-organizational problems (i.e., contradictions) among the participants in the FNA project have collectively led to its expansive development and reconceptualization, which in turn, at least potentially, provides a more hospitable environment for the development and deployment of CPS as a publishing coordination environment and viably sustainable boundary infrastructure (Bowker \& Star, 1999). A couple of the steps that Engeström includes in cycles of expansive development will perforce be the focus of future work. An additional way in which this presentation simplifies actual cycles of expansive development is by suggesting that the steps progress in a linear fashion, with no overlap between them. In fact, reality as lived and experienced is never so tidy. With respect to FNA, the transformative potential for the Project as a whole was prefigured and at least partially modeled by the emergence shortly after this research began of a de facto bryoflora editorial center at the New York Botanical Garden.

${ }^{12}$ The analysis that follows is based on Blackler et al.'s (see Blackler, Crump, \& McDonald, 1999, forthcoming; Blackler, Kennedy, \& Reed, 1999) creative synthesis and elaboration of Engeström's (1991, 1993, 1996) model for developmental work research.

${ }^{13}$ In a fascinating discussion of human error in complex systems, Reason (1990) distinguishes between active errors and latent errors, the effects of the latter perhaps remaining dormant within a system for years. As Engeström (1991) mentions, this “... analogy between latent failures in complex systems and 'resident pathogens' in the human body" (p. 265) is heuristically exciting, but heretofore under-theorized, at least as a tool suitable for analyzing latent failures (viz. open discoordinations, hidden ruptures in intersubjective understandings, etc.). However, realist activity theory does at least begin to underwrite such analogical reasoning with its strong emphasis of internal contradictions/tensions/incoherencies as mechanisms necessarily generative of systemic change and development. 


\section{REFERENCES}

Archer, M. S. (1995). Realist social theory: the morphogenetic approach. Cambridge, UK: Cambridge University Press.

Archer, M. S. (1996). Social integration and system integration: developing the distinction. Sociology, 30(4), 679-699.

Archer, M. S. (1998). Social theory and the analysis of society. In T. May, \& M. Williams (Eds.), Knowing the social world (pp. 69-85). Buckingham, UK: Open University Press.

Archer, M. S., Bhaskar, R., Collier, A., Lawson, T., \& Norrie, A. (Eds.) (1998). Critical realism: essential readings. London: Routledge.

Aronson, J. L., Harré, R., \& Way, E. C. (1995). Realism rescued: how scientific progress is possible. Chicago: Open Court.

Bhaskar, R. (1978). A realist theory of science (2nd ed.). Brighton: Harvester.

Bhaskar, R. (1986). Scientific realism and human emancipation. London: Verso.

Bhaskar, R. (1989). The possibility of naturalism: a philosophical critique of the contemporary human sciences (2nd ed.). Brighton: Harvester Wheatsheaf.

Bishop, A. P., \& Star, S. L. (1996). Social informatics of digital library use and infrastructure. Annual Review of Information Science and Technology, 31, 301-401.

Blackler, F. (1995). Knowledge, knowledge work and organizations: an overview and interpretation. Organization Studies, 16(6), 1021-1046.

Blackler, F., Crump, N., \& McDonald, S. (1999). Managing experts and competing through innovation: an activity theoretic analysis. Organization: The Interdiscplinary Journal of Organization, Theory and Society, $\underline{6}(1), 5-31$.

Blackler, F., Crump, N., \& McDonald, S. (forthcoming). Organizing processes in complex activity networks. Organization: The Interdisciplinary Journal of Organization, Theory and Society, $\underline{7}(2)$.

Blackler, F., Kennedy, A., Reed, M. (1999). Organising for incompatible priorities. In A. Mark, S. Dopson, \& R. Stewart (Eds.), Organisational Behaviour in Health Care. London: Macmillan.

Boland, R. J. Jr., \& Tenkasi, R. V. (1995). Perspective making and perspective taking in communities of knowing. Organization Science, 6(4), 350-372.

Bowker, G. C., \& Star, S. L. (1999). Sorting things out: classification and its consequences. Cambridge, MA: MIT Press.

Collier, A. (1994). Critical realism: an introduction to Roy Bhaskar's philosophy. London: Verso.

Elliott, M., \& Kling, R. (1997). Organizational usability of digital libraries: case study in legal research in civil and criminal courts. Journal of the American Society for Information Science, 48(11), 1023-1035.

Engeström, Y. (1987). Learning by expanding: an activity-theoretical approach to developmental research. Helsinki: Orienta-Konsultit Oy. 
Engeström, Y. (1990). Learning, working, and imagining: twelve studies in activity theory. Helsinki: Orienta-Konsultit Oy.

Engeström, Y. (1991). Developmental work research: reconstructing expertise through expansive learning. In M. I. Nurminen, \& G. R. S. Weir (Eds.), Human jobs and computer interfaces (pp. 265-290).

Amsterdam: Elsevier Science Publishers.

Engeström, Y. (1993). Developmental studies of work as a testbench of activity theory: the case of primary care medical practice. In S. Chaiklin, \& J. Lave (Eds.), Understanding practice: perspectives on activity and context (pp. 64-103). Cambridge, UK: Cambridge University Press.

Engeström, Y. (1995). Objects, contradictions and collaboration in medical cognition: an activitytheoretical approach. Artificial Intelligence in Medicine, 7, 395-412.

Engeström, Y. (1996). Developmental work research as educational research: looking ten years back and into the zone of proximal development. Nordisk Pedagogik, 16(3), 131-143.

Engeström, Y., Miettinen, R., Punamäki, R.-L. (Eds.) (1999). Perspectives on activity theory. Cambridge, UK: Cambridge University Press.

Fleetwood, S. (Ed.). (1999). Critical realism in economics: development and debate. London: Routledge.

Greenwood, J. D.(1994). Realism, identity, and emotion: reclaiming social psychology. Thousand Oaks, CA: Sage.

Harré, R. (1970). The principles of scientific thinking. London: Macmillan.

Harré, R. (1986). The varieties of realism: a rationale for the natural sciences. Oxford: Blackwell Scientific.

Harré, R., \& Secord, P. F. (1972). The explanation of social behaviour. Oxford: Blackwell Scientific.

Hasan, H., Gould, E., \& Hyland, P. (Eds.) (1998). Information systems and activity theory: tools in context. Wollongong, Australia: University of Wollongong Press.

Henry, G. T., Julnes, G., \& Mark, M. M. (Eds.). (1998). Realist evaluation: an emerging theory in support of practice (New Directions for Evaluation No. 78). San Francisco: Jossey-Bass Publishers.

Hjørland, B. (1997). Information seeking and subject representation: an activity-theoretical approach to information science. Westport, CT: Greenwood Press.

Isaac, J. C. (1987). After empiricism: the realist alternative. In T. Ball (Ed.), Idioms of inquiry: critique and renewal in political science (pp. 187-205). Albany, NY: State University of New York Press.

Keat, R., \& Urry, J. (1982). Social theory as science (2nd ed.). London: Routledge \& Kegan Paul.

Kuutti, K. (1991). The concept of activity as a basic unit of analysis for CSCW research. In ECSCW'91:

Proceedings of the Second European Conference on Computer-Supported Cooperative Work (pp. 360-376). Dordrecht: Kluwer.

Lawson, T. (1989). Realism and instrumentalism in the development of econometrics. In C. Gilbert, \& N. De Marchi (Eds.), History and methodology of econometrics . Oxford: Oxford University Press.

Lawson, T. (1994). A realist theory for economics. In R. E. Backhouse (Ed.), New directions in economic methodology (pp. 257-285). London: Routledge. 
Lawson, T. (1997). Economics \& reality. London: Routledge.

Layder, D. (1994). Understanding social theory. London: Sage.

Layder, D. (1985). Beyond empiricism? The promise of realism. Philosophy of the Social Sciences, 15 , 255-274.

Layder, D. (1997). Modern social theory: key debates and new directions. London: UCL Press.

Layder, D. (1998). Sociological practice: linking theory and social research. London: Sage.

Magill, R. E., Barkley, T. M., Morin, N. R., Schnase, J. L., \& Thiers, B. M. (1999). Flora of North

America: a framework of the construction and long-term maintenance of North American botanical

knowledge.

Manicas, P. T. (1987). A history and philosophy of the social sciences. Oxford: Blackwell Science.

Manicas, P. T. (1993). Accounting as a human science. Accounting, Organizations and Society, 18(2/3), 147-161.

Manicas, P. T., \& Secord, P. F. (1983). Implications for psychology of the new philosophy of science.

American Psychologist, 38, 399-413.

McLennan, G. (1981). Marxism and the methodologies of history. London: Verso.

Morin, N. R. (1991). Beyond the hardcopy: databasing Flora of North America information. In The unity of evolutionary biology, Proceedings of the International Congress for Systematic and Evolutionary Biology

IV (pp. 973-980). Portland: Dioscorides Press.

Morin, N. R., Whetstone, R. D., Wilken, D., \& Tomlinson, K. L. (Eds.) (1989). Floristics for the 21st century: proceedings of the workshop sponsored by the American Society of Plant Taxonomists and the Flora of North America Project St. Louis, MO: Missouri Botanical Garden.

Morris, B. (1997). In defence of realism and truth: critical reflections on the anthropological followers of Heidegger. Critique of Anthropology, 17(3), 313-340.

Nardi, B. (Ed.) (1996). Context and consciousness: activity theory and human-computer interaction.

Cambridge, MA: MIT Press.

Näslund, T. (1997). Computers in context - but which context? In M. Kyng, \& L. Mathiassen (Eds.), Computers and design in context (pp. 171-200). Cambridge, MA: MIT Press.

Orlikowski, W. J. (1993). CASE tools as organizational change: investigating incremental and radical changes in systems development. MIS Quarterly, 17(3), 309-340.

Outhwaite, W. (1987). New philosophies of social science: realism, hermeneutics and critical theory. Basingstoke, UK: Macmillan.

Pateman, T. (1987). Language in mind and language in society. Oxford: Clarendon Press.

Pawson, R. (1989). A measure for measures: a manifesto for empirical sociology. London: Routledge.

Pawson, R. (1996). Theorizing the interview. British Journal of Sociology, 47(2), 295-314.

Pawson, R. (undated). Middle-range realism. 
Pawson, R., \& Tilley, N.(1997). Realistic evaluation. London: Sage.

Reason, J. T. (1990). Human error. Cambridge, UK: Cambridge University Press.

Ryan, S., \& Porter, S. (1996). Breaking the boundaries between nursing and sociology: a critical realist ethnography of the theory-practice gap. Journal of Advanced Nursing, 24, 413-420.

Sánchez, J. A. (1998) Improving the collaborative use of information spaces by enhancing group awareness [Web Page]. URL http://ict.pue.udlap.mx/pubs/cscw98.html [1998, December 7].

Sayer, A. (1985). Realism in geography. In R. J. Johnston (Ed.), The future of geography (pp. 159-173). London: Methuen.

Sayer, A. (1992). Method in social science: a realist approach (2nd ed.). London: Routledge.

Schnase, J. L., Kama, D. L., Tomlinson, K. L., Sánchez, J. A., Cunnius, E. L., \& Morin, N. R. (1997). The Flora of North America digital library: a case study in biodiversity database publishing. Journal of Network and Computer Applications, 20, 87-103.

Spasser, M. A. (1998). Computational Workspace Coordination: Design-in-Use of Collaborative

Publishing Services for Computer-Mediated Cooperative Publishing. Unpublished doctoral dissertation, University of Illinois, Urbana, IL.

Spasser, Mark A. (2000). Articulating collaborative activity: design-in-use of Collaborative Publishing Services in the Flora of North America Project. Scandinavian Journal of Information Systems, 12(1), 149172.

Star, S. L. (1989). The structure of ill-structured solutions: boundary objects and heterogeneous distributed problem solving. In M. Huhs, \& L. Gasser (Eds.), Readings in distributed artificial intelligence 3 (pp. 3754). Menlo Park, CA: Morgan Kaufmann.

Star, S. L., \& Griesemer, J. R. (1989). Institutional ecology, 'translations' and boundary objects: amateurs and professionals in Berkeley's Museum of Vertebrate Zoology, 1907-39. Social Studies of Science, 19, $387-420$.

Stones, R. (1996). Sociological reasoning: towards a past-modern sociology. New York: St. Martin's Press.

Tomlinson, K. L., Spasser, M. A., Sánchez, J. A., \& Schnase, J. L. (1998). Managing cognitive overload in the Flora of North America project. In HICSS-31: Proceedings of the Hawaii International Conference on Systems Sciences, Vol. II: Digital Documents Track (pp. 296-304). Los Alamitos, CA: IEEE Computer Society Press.

Tomlinson, K. L., Spasser, M. A., \& Schnase, J. L. (forthcoming). Flora of North America: a distributed cognitive system. In WebNet' 97 Proceedings Online .

Wainwright, S. P. (1997). A new paradigm for nursing: the potential of realism. Journal of Advanced Nursing, 26, 1262-1271.

Weber, M. (1947). The theory of social and economic organization. New York: Free Press.

Wenger, E.(1998). Communities of practice: learning, meaning, and identity. Cambridge, UK: Cambridge University Press.

Will, D. (1980). Psychoanalysis as a human science. British Journal of Medical Psychology, 53, 201-211. 
Yeung, W.-C. H. (1997). Critical realism and realist research in human geography: a method or a philosophy in search of a method? Progress in Human Geography, 21(1), 51-74.

Yin, R. K.(1994). Case study research: design and methods (2nd ed.). Thousand Oaks, CA: Sage.

Zuboff, S.(1989). In the age of the smart machine : the future of work and power. New York: Basic Books. 